УДК $811.161 .2: 81^{\prime} 37$

\title{
КОНЦЕПТ ЗГОДА: УНІВЕРСАЛІЯ МОДЕЛІ ЗЛАГОДЖЕНОГО СПІЛКУВАННЯ
}

\author{
Людмила Білоконенко \\ Криворізький державний педагогічний університет \\ Kryvyi Rih State Pedagogical University \\ пр. Гагаріна, 54, Кривий Ріг, 50086, Україна \\ bk.ludmila1020@gmail.com
}

\begin{abstract}
Білоконенко Л. Концепт згода: універсалія моделі злагодженого спілкування

У статті акцентовано увагу на широкому витлумаченні концепту згода, який репрезентує етичні уявлення індивідів про злагоджену комунікацію та належить до важливих характеристик їхньої поведінки в суспільстві. На підставі аналізу словникових дефініцій зроблено висновок, що у змістовій структурі концепту згода визначаються етимологічно успадковані й сучасні потрактування. 3'ясовано, що перші грунтовані на логіко-філософських та етичних категоріях; другі засвідчують прагматичні установки сьогоденної етномовної свідомості українців.

Ключові слова: концепт згода, злагоджене спілкування, етимологічна та сучасна лінгвоспецифіка, семантична інтерпретація.
\end{abstract}

Белоконенко Л. Концепт согласие: универсалия модели слаженного общения

В статье акцентируется внимание на широком понимании концепта согласие, который репрезентирует этические представления людей о слаженной коммуникации и относится к важным характеристикам их поведения в обществе. На основании анализа словарных дефиниций делается вывод, что в содержательной структуре концепта согласие определяются этимологически унаследованные и современные толкования. Устанавливается, что первые основаны на логико-философских и этических категориях; вторые свидетельствуют о прагматических установках сегодняшнего этноязыкового сознания украинцев.

Ключевые слова: концепт согласие, слаженное общение, этимологическая и современная лингвоспецифика, семантическая интерпретация. 
Bilokonenko L. Concept of consent: universal model of concerted communication

The author of the article refers to the wide interpretation of the concept of consent, which represents the ethical concepts of effective communication, belongs to the important characteristics of the behaviour of the individual in society. Thescientific consideration of the concept from the standpoint of language, the clarification of its cognitive and pragmatic features, makes it possible to identify one of many motivational forms of the mental representation of knowledge about concerted communication.

In the perception of the concept, we could find a pragmatic approach, such as: "understanding, consensus, agreement, confirmation, assignment".

By the analysis of the vocabulary definitions, we conclude that the content structure of the concept has etymologically inherited and modern interpretations.

Firstly, the concept of consent is etymologically correlated with the logicalphilosophical and ethical categories and concepts, and imply peace, goodness, truth, the ability of the interlocutor to the desired actions. From etymological preconditioned interpretation of "peaceful" it was inherited meaning "harmony, friendship, order, agreement, consistency". Secondly, over time, the basic constant of the concept "peaceful" was supplemented, reflecting the modern ethno-linguistic consciousness of Ukrainians.

In the perception of the concept, we could find a pragmatic approach, such as: "understanding, consensus, agreement, confirmation, assignment". Therefore, in contemporary dictionaries, the concept of consent is widely interpreted, enabling its semantic interpretation in the plane of cooperation, compromise, avoidance and assignment.

Key words: concept of consent, concerted communication, etymological and modern linguospecificity, semantic interpretation.

Постановка проблеми та її зв'язок із важливими науковими завданнями. Концепт - багатовимірне ментальновербальне утворення, воно містить принаймні три складники: поняттєвий, образний, знаковий; останній надає йому статусу лінгвістичного об'єкта. М. Скаб визнає: це “абстрактна одиниця ментального рівня <..> відбиває зміст результатів пізнання людиною довкілля та в якій зосереджено відомості про пізнаваний об'єкт, його властивості, місце в культурі народу й результати емоційно-оцінного сприйняття цього фрагмента світу <..> Концепти здатні розростатися і збагачуватися завдяки індивідуальному емоційному і культурному досвіду носіїв мови" [Skab / Скаб 2009 : 5-6]. А. Мартинюк у Словнику основних термінів когнітивно-дискурсивної лінгвістики зазначає: поняття “розуміється як “готове знання”, ментальна 
репрезентація досвіду, продукт віддзеркалення суб'єктом об'єктивного реального світу (об'єктивізм) або продукт розумової діяльності суб'єкта, що репрезентує світ конструкцію, яка перебуває у свідомості суб'єкта і відбиває не світ як такий, а його уявлення про світ (суб'єктивізм)" [Martynyuk / Мартинюк 2012 : 38]. Знакова лінгвістична природа передбачає реалізацію вербальними засобами, сукупність яких $\epsilon$ планом вираження відповідного лексико-семантичного поля, вибудуваного навколо домінанти (ядра) - “імені” концепту, тобто слова або його семантичного варіанта. Багатозначні лексеми вможливлюють опис концепту через взаємозв'язки синонімії (омонімії) у словниковій статті. До характеристик цієї одиниці ментального рівня також зараховують співвідношення частиномовних реалізацій, словотвірну продуктивність, однак значущими вважають прагмалінгвістичні властивості лексикограматичних одиниць, які реалізуються в синонімічному ряду. Дослідники висловлюють думку: семантичний аспект концепту формується 3 синтагматичних i парадигматичних зв'язків, а мовний параметр значення має культурологічну орієнтацію.

Поряд із теоретичними розробленнями цієї категорії науковці вдаються до спроб представити опис тих чи тих концептів. У лінгвістичних працях простежуємо аналіз “ключових констант”, які організовують універсум української мови, відбивають нашу етномовну свідомість. Серед них ті, що формулюють вихідні положення принципу злагодженого (безконфліктного, кооперативного) спілкування як ситуації комфорту для іiі учасників. У цьому разі виправдано можна звернутися до поняттєвого змісту концептів, які вможливлюють кооперативний контакт між мовцями.

Аналіз останніх досліджень та публікацій. Різні аспекти мовної концептуалізації в українській та / або англійській, польській, німецькій та інших мовах розглядаються в роботах вітчизняних дослідників, а саме: концепти "чоловік і жінка" [Bondarenko / Бондаренко 2005], “рід, родина, сім’я” [Makarets, Slipchuk / Макарець, Сліпчук 2013], “воля / свобода” [Vasylenko / Василенко 2016], “щастя” [Drobishevska / Дробішевська 2011; Diakonova / Д'яконова 2012], “віра” [Kolomiiets / Коломієць 
2014], "гроші" [Malynovska / Малиновська 2010], “культура" [Misinkevych / Місінькевич 2014], сакральної сфери [Skab / Скаб 2009] тощо. Категорія згоди також була об'єктом лінгвістичної уваги (на матеріалі художньої літератури) [Voitsekhivska / Войцехівська 2009]. Проте є потреба звернутися до ширшого потрактування концепту згода, значущого для усвідомлення важливого фрагменту людського досвіду, який репрезентує етичні уявлення українців про ефективну комунікацію, належить до важливих характеристик поведінки індивіда в суспільстві та виявляється в багатьох видах дискурсу. Науковий розгляд категорій, пов'язаних із концептом згода з позиції мови, 3'ясування когнітивних і прагматичних ознак цього концепту вможливлює визначення однієї з мотиваційних форм ментальної репрезентації знань про безконфліктне спілкування.

Мета нашої наукової розвідки: схарактеризувати концепт згода як універсалію злагодженого спілкування для носіїв української лінгвокультури.

Засадничі завдання: аналізуючи словникові дефініції, з'ясувати поняттевий зміст концепту згода; визначити мотиваційні форми обрання такого способу злагодженого спілкування як згода зі співрозмовником.

Виклад основного матеріалу дослідження. Про злагоджене спілкування сучасні дослідники говорять як про потрібне, але суперечливе, фундаментально неоднозначне явище. Адже за такого контакту мовців мають на меті не лише доброзичливі слова або корисні дії. Це ситуація, коли людині для нейтралізації конфлікту треба погодитися з думками, діями іншого та, водночас, поступитися власним правом на самовизначення. Таку складну взаємодію вможливлює культура спілкування, що $\epsilon$ основою кооперативних установок громадської свідомості. Культура спілкування окреслює норми та принципи співжиття індивідів у суспільстві, а ії вияв - етикет, тобто правила мовної та позамовної поведінки людей, які організують відношення між ними в різних буттєвих ситуаціях. Злагоджені стосунки - етикетна категорія міжособистісної поведінки, що діє на рівні відносин осіб і через них стає суспільним позитивним явищем.

() Л. Білоконенко, 2018. 
Унеможливлення протистояння у спілкуванні передбачає взаємне пристосування або адаптацію, коли хоча б один із мовців намагається “обійти” перешкоду. Така поведінка має своєю умовою використання певних засобів мовного впливу на адресата, спрямованих на злагоду. У цьому плані мовне поле кооперативності формується завдяки ввічливому тону, дотриманню правил етикету, приязному ставленню до партнера; умінню промовчати, пояснити, визнати провину, вибачитися; конструктивним пропозиціям, зміні теми, “амортизації”, а також згод $i$, тобто продуктам розумової діяльності особи, що репрезентують безконфліктний світ. Недопущення суперечки можливе, якщо індивіди усвідомлюють виникнення проблемної ситуації та обирають певний спосіб ії̈ уникнення.

У словниках поняття згода розкривають через синонімічні ряди, члени яких вирізняються семантичними відтінками. 3'ясуємо його зв'язок 3 іншими близькими поняттями: структурування значень слів, що окреслюють концепт згода, вможливлює висновки щодо категорійно-поняттєвого поля.

Насамперед звернімося до етимологічного зв'язку слова згода $з$ іншими словами української мови та споріднених мов. В етимологічному словнику зазначено: лексема згода (згідливий) “придатний; миролюбний” етимологічно та генетично пов'язана 3 коренем ghad-(ghod-), зреалізованим у різних мовах у словах зі значенням: середньонижньонімецьким "бути відповідним, пасувати”, давньоанглійським “товариш, дружина (чоловік)”, готським “свояк, родич”, давньофризьким “об'єднувати” тощо; має відповідники в англійській "разом, спільно", литовській “честь, слава, частування”, латиській “здатний, шановний”, польській "бенкет", чеській "храмове свято, бенкет”, сербохорватській "свято"; походить від індоєвропейського кореня ghedh-/ghodh- із розвитком семантики “відповідний, добрий” та глибшою етимологією від давньоіндійського gadhya(“об'єднувати”) [Etymolohichnyi / Етимологічний 1982 : 544-545]. Визначена константа “миролюбний” (приязний, дружелюбний) $є$ базовою для безконфліктної самосвідомості людини; також вона повністю зберігає свою культурно- 
мотивувальну базу “оснований на мирі, дружбі” та є відбиттям історично сформованої спрямованості на злагоджений контакт.

Слово має корінь -год- (-2ід-), спорідненими до нього є: гідний (“вартий чогось”), годен (“здатний”), годити (“вдаватися, щастити”), годливість (“справедливість”), вгідний (“відповідний”), вигідний (“корисний, зручний”), вигода (“користь”), догідний (“зручно”), догода (“догождання”), догоджати (“"задовольняти”), угідний та угодливий (“добрий”), угода (“домовленість, догоджання”), угодний (“зручний”), угодник (“догідний, зручний”) [там само].

Етимологічну лінгвоспецифіку концепту згода визначаємо за тим, що у словниковій статті споріднені слова мають цілком прозорий словотворчий зв'язок із реєстровим словом, хоча змістова сторона й має значний спектр прояву. Спорідненість фіксуємо у смислових інтерпретаціях:

1. Миролюбний.

2. Добрий, справедливий, шанований.

3. Користь, корисний, зручний, зручно.

4. Домовленість, догоджання, задовольняти, здатний.

Наведені витлумачення унаочнюють генетичні зв'язки концепту згода з іншими поняттями.

По-перше, спостерігаємо типову широку залежність від злагодженого спілкування, підпорядкованого меті досягнення взаєморозуміння між сторонами: миролюбний - не схильний до війни, ворожнечі чи сварок.

По-друге, визначається зв'язок із важливими етичними категоріями: добро (добра людина $є$ приязною, чуйною) та справедливість (справедлива особа не має упереджень, об'єктивно ставиться до інших). Така особа викликає пошану (вона шанована, бо визнають ії чесноти, позитивні якості).

По-третє, оскільки згода засвідчує близькість думок, позицій, дій суб'єктів та грунтована на повному або частковому збігу поглядів мовців на предмет розмови, то співрозмовник, погоджуючись, стає для іншої особи корисним (приносить добрі наслідки, дає користь), зручним (не завдає клопоту, неприємностей, тому 3 ним зручно). Згода набуває додаткової 
конотації, адже вможливлює індивіду реалізацію власного комунікативного наміру, якому “зручний” адресат не заважає.

По-четверте, згоду забезпечує певна поведінка індивіда, який не лише не заважає комусь, а й допомагає змістом та формою свого висловлення. Тоді комунікативний партнер відкритий для домовленостей (дотримується попередньо досягнутих умов), догоджск (робить щось приємне, потрібне для адресанта), задовольняє (виконує вимоги, дає бажане, потрібне) та здатний на таку поведінку (уміє виконувати, робити те, що потрібне іншій стороні).

Як бачимо, концепт згода етимологічно співвідноситься 3 логіко-філософськими та етичними категоріями, поняттями та передбачає мир, добро, істину, відсутність неприємних наслідків та здатність контактера до бажаних дій.

Зосередимося на пізніших реєстрових базах. «Словарь української мови» за ред. Б. Грінченка визначає лексему згода як “согласіе; миръ" та “соглашеніе, примиреніе" [Slovar / Словарь 1907-1909:915]. У філософському словнику трактована в межах поняття компроміс, яке витлумачене як “Згода, порозуміння супротивників, досягнуті взаємними поступками" [Filosofskyi / Філософський 2002:290]. У словнику синонімів подано гніздове слово згода - це позитивна відповідь; дозвіл; порозуміння, погодженість, узгодженість; одностайність, злагода, гармонія, лад [Karavanskyi / Караванський 2004:129]. У синонімічних рядах інших гніздових слів також наведено слово згода: злагода - згода, гармонія, мир, дружба, мирність, лад, погодженість, узгодженість [там само: 142]; лад - згода, злагода [там само : 184]; мир - згода, злагода, лад; відсутність війни; мирна угода, замирення [там само: 203]; одностайність - єдність; згода [там само : 260]; порозуміння - згода, взаєморозуміння; погодженість, узгодженість [там само : 315].

Словник української мови подає значення лексеми: 1. Позитивна відповідь, дозвіл. 2. Взаємна домовленість; порозуміння. 3. Спільність поглядів, думок; одностайність. 4. Взаємна дружба, мирні стосунки. 5. Союз, об'єднання. 
6. ствердж. частка. підтвердження чого-небудь, погодження 3 чимось [Slovnyk / Словник 1972 : 516].

У сучасній концептуальній формулі згоди визначаємо семантичні інтерпретації:

1. Значення, у якому виявляється момент, що доводить обставини постійних мирних стосунків людей: незалежно від ситуації вони налаштовані на мир, головно погоджуються 3 чимось, а саме: гармонія (поєднання, злагодженість), одностайність (злагодженість, дружні стосунки), дружба (відносини, в основі яких взаємна прихильність, довіра, спільність інтересів тощо), лад (злагода у взаємовідношеннях), злагода (мирні, дружні відносини, гармонія між особами), злагодженість (погодженість дій, одностайність), спільність (поглядів, думок), узгодженість (єдність між суб'єктами). Це згода, для якої характерний збіг думок, переконань, почуттів індивідів за відсутності суперечностей. Таке витлумачення узгоджується зі співробітництвом, передбачає високий рівень спрямованості на спільні інтереси, коли мовці повинні докладати зусилля, щоб дотриматися принципу миролюбності і справедливості, що й має першорядне значення в підтримці мирних стосунків.

2. Суть 3'ясовується завдяки лексемам, що окреслюють тимчасовий (частковий) характер збігу поглядів на предмет розмови: згода діє протягом деякого періоду, за домовленістю: порозуміння (взаємна домовленість, погодженість у діях зі співрозмовником), погодженість (досягнення взаємної угоди), домовленість (умова, якої досягають попередніми переговорами), союз (угода, домовленість про щось). У такому разі суб'єкти погоджуються 3 чимось задля компромісу, який уможливлює подальший розвиток стосунків.

3. Розуміння як мовленнєвого кроку, що потребує позитивної реакції на акцію: позитивна відповідь (підтвердження чогось очікуваного), підтвердження (засвідчення правильності, правдивості чогось). Трактування орієнтоване на уникнення протидії, це спроба людини ухилитися від боротьби, можливим $\epsilon$ й компромісне погодження.

(с) Л. Білоконенко, 2018. 
4. Останнім за лексикографічною значущістю $\epsilon$ витлумачення словом поступка (повна або часткова згода 3 ким-небудь, відмова від власних інтересів на вимогу іншого). У цьому плані згоду сприймають як бажання суб'єкта поступитися своїми інтересами для збереження взаємостосунків, що видаються важливішими за обставини контакту.

Концепт згода від етимологічного зумовленого потрактування “миролюбний” першорядно успадкував розуміння “гармонія, дружба, лад, злагода, узгодженість”, що й передбачає мир, єдність між особами. Згодом логікофілософські та етичні категорії й поняття поступилися прагматичному підходу, як-от: “порозуміння, погодженість, домовленість, підтвердження, поступка" - мовленнєві кроки, які $\epsilon$ спробою ухилитися від суперечок, оскільки вони невигідні.

Згода стає важливим механізмом уникнення конфліктів та злагодженого спілкування, який реалізується різними мовними засобами. Погодитися зі співрозмовником можна сказавши: Добре; Так, я розумію, тобі було важко; Я розумію (відчуваю) твій стан (почуття, настрій); Добре, щуо ти мені про це розказав; Яз тобою повністю згодна тощо. Це формули психологічного приєднання до іншого та його емоцій. Як антоніми до поняття “конфлікт" науковці пропонують саме смислові одиниці “згода" та "гармонія”, а межа диференціації концепту "конфлікт" - гармонійна взаємодія, із повагою, компромісом, дотриманням норм і правил соціуму, взаємним сприйняттям цінностей i потреб іншої людини, що i вможливлюють згода та злагода. В офіційному та неофіційному мовленні використання засобу переважно $\epsilon$ успішним та забезпечує позитивний зв'язок між людьми.

Висновки та перспективи подальших наукових розвідок. Застосувавши одну з поширених методик дослідження концепту, а саме аналіз словникових дефініцій, ми пересвідчилися: у змістовій структурі концепту згода визначаються етимологічно успадковані та сучасні потрактування, які характеризують його цінність для носіїв української культури. Базова константа концепту “миролюбний” iз часом доповнюється, відбиваючи сучасну етномовну 
свідомість українців. У своєму прагненні до комфортного спілкування особи не сприймають згоду тільки як механізм для гармонійного контакту, тому не уникають тимчасового пристосування до іншого, тобто погоджуються ситуативно. Унаслідок у сучасних словниках концепт згода трактується широко, уможливлюючи його смислову інтерпретацію у площині не лише співробітництва, а й компромісу, уникнення, поступки.

\section{Перспективи подальшого дослідження вбачаємо в} поглибленому аналізі мовних засобів, які репрезентують згоду.

\section{Література}

1. Бондаренко О. С. Концепти “чоловік” і “жінка” в українській та англійській мовних картинах світу : автореф. дис. ... канд. філол. наук : 10.02.17. Донецьк, 2005. 19 с.

2. Василенко О. М., Семенишин О. I. Лінгвокультурні концепти "Воля / Свобода (Liberty / Freedom)". Гілея : науковий вісник : зб. наук. праць. Київ, 2016. Вип. 104 : “Філософські науки”. С. 116-119.

3. Войцехівська Н. К. Категорія згоди в українському літературному діалогічному дискурсі (на матеріалі художньої літератури XX - поч. XXI століть) : дис. ... канд. філол. наук : 10.02.01. Київ, 2009. 288 с.

4. Дробішевська У. Концепт “щастя” в українській і польській фразеології. Етнос і культура. 2011. № 8-9. С. 125-130.

5. Д'яконова О. В. Вербалізація концепту ЩАСТЯ в німецькій та українській лінгвокультурах: на матеріалі романтичної лірики XIX ст. Мовні $і$ концептуальні картини світу. 2012. Вип. 41. Ч. 2. С. 20-26.

6. Етимологічний словник української мови : у 7 т. / НАН України, Інститут мовознавства ім. О. О. Потебні. Київ : Наукова думка. Т. 1: А-Г / уклад.: Р. В. Болдирєв та ін. 1982. 632 с.

7. Караванський $C$. Й. Практичний словник синонімів української мови. 2-е вид. Київ : Українська книга, 2004. 448 с.

8. Коломієць К. Концепт віри в українській мові. URL :http:// ukrconf.fl.kpi.ua/wp-content/uploads/2014/12/51._Kolomiyets_Kateryna. pdf (дата звернення: 12.10.2018).

9. Макарець Ю. С., Сліпчук О. М. Концепти рід, родина, сім'я в мовній картині світу українців. Наукові записки Ніжинського державного університету ім. Миколи Гоголя. Серія : Філологічні науки. Ніжин, 2013. Кн. 1. C. $75-78$.

10. Малиновська Г. Концепт "ГРОШІ" в українській мовній картині світу. Украӥнська мова. 2010. № 4. С. 75-84.

11. Мартинюк А. П. Словник основних термінів когнітивно-дискурсивної лінгвістики. Харків, 2012. 196 с.

12. Місінькевич О. Концепт культури як одиниця ментальної інформації у

(с) Л. Білоконенко, 2018. 
мовній картині світу. Мандрівещьь. 2014. № 1. С. 53-57.

13. Скаб М. В. Концептуалізація сакральної сфери в українській мові : автореф. дис. ... д-ра філолог. наук : 10.02.01. Київ, 2009. 36 с.

14. Словарь української мови : у 4-х т. / за ред. Б. Д. Грінченка. Київ, $1907-$ 1909. URL : https://r2u.org.ua/data/Словарь української мови (1907-1909). pdf (дата звернення: 15.10.2018)

15. Словник української мови : в 11-ти т. / АН УРСР. Інститут мовознавства ; за ред. І. К. Білодіда. Київ, 1970-1980. Т. 3. 1972.744 с.

16. Філософський енциклопедичний словник / голов. ред. В. І. Шинкарук. Київ, 2002. 742 с. URL : http://shron1.chtyvo.org.ua/ Shynkaruk_Volodymyr/ Filosofskyi_entsyklopedychnyi_slovnyk.pdf (дата звернення: 14.10.2018).

\section{References}

1. Bondarenko O. S. Kontsepty "cholovik" i "zhinka" v ukrainskii ta anhliiskii movnykh kartynakh svitu [Concepts of "man" and "woman" in Ukrainian and English language pictures of the world] : avtoref. dys. ... kand. filol. nauk : 10.02.17. Donetsk, 2005. 19 s.

2. Vasylenko O. M., Semenyshyn O. I. Linhvokulturni kontsepty "Volia / Svoboda (Liberty / Freedom)" [Linguocultural concepts of "Liberty / Freedom (Liberty / Freedom)"]. Hileia: naukovyi visnyk : zb. nauk. prats. Kyiv, 2016. Vyp. 104 : "Filosofski nauky". S. 116-119.

3. Voitsekhivska N. K. Katehoriia zghody v ukrainskomu literaturnomu dialohichnomu dyskursi (na materiali khudozhnoi literatury XX - poch. XXI stolit) [Category of agreement in the Ukrainian literary dialogical discourse (on the material of fiction XX - early XXI centuries)] : dys. ... kand. filol. nauk : 10.02.01. Kyiv, 2009. $288 \mathrm{~s}$.

4. Drobishevska U. Kontsept "shchastia" v ukrainskii i polskii frazeolohii [Concept of "happiness" in Ukrainian and Polish phraseology]. Etnos i kultura. 2011. № 8-9. S. 125-130.

5. Diakonova O. V. Verbalizatsiia kontseptu SHCHASTIA $v$ nimetskii ta ukrainskii linhvokulturakh: na materiali romantychnoi liryky XIX st. [Verbalization of the concept of HAPPINESS in German and Ukrainian linguistic cultures: based on the material of romantic lyrics of the XIXth cent.]. Movni i kontseptualni kartyny svitu. 2012. Vyp. 41. Ch. 2. S. 20-26.

6. Etymolohichnyi slovnyk ukrainskoi movy : u 7 t. [The etymological dictionary of the Ukrainian language] / NAN Ukrainy, Instytut movoznavstva im. O. O. Potebni. Kyiv : Naukova dumka. T. 1: A-H / uklad.: R. V. Boldyriev ta in. 1982. $632 \mathrm{~s}$.

7. Karavanskyi S. Y. Praktychnyi slovnyk synonimiv ukrainskoi movy [Practical dictionary of synonyms of the Ukrainian language]. 2-e vyd. Kyiv : Ukrainska knyha, 2004. $448 \mathrm{~s}$.

8. Kolomiiets K. Kontsept viry $\mathrm{v}$ ukrainskii movi [Concept of faith in the Ukrainian Language]. URL : http://ukrconf.fl.kpi.ua/wp-content/uploads/2014/12/ 51._Kolomiyets_Kateryna.pdf(data zvernennia: 12.10.2018).

9. Makarets Yu. S., Slipchuk O. M. Kontsepty rid, rodyna, simia v movnii kartyni svitu ukraintsiv [Concepts of generation, family, kin in the Ukrainian 
language picture of the world]. Naukovi zapysky Nizhynskoho derzhavnoho universytetu im. Mykoly Hoholia. Seriia: Filolohichni nauky. Nizhyn, 2013. Kn.1. S. 75-78.

10. Malynovska H. Kontsept "HROSHI" v ukrainskii movnii kartyni svitu [Concept "MONEY" in the Ukrainian language picture of the world]. Ukrainska mova. 2010. № 4. S. 75-84.

11. Martyniuk A. P. Slovnyk osnovnykh terminiv kohnityvno-dyskursyvnoi linhvistyky [Dictionary of basic terms of cognitive-discursive linguistics]. Kharkiv, 2012. $196 \mathrm{~s}$.

12. Misinkevych O. Kontsept kultury yak odynytsia mentalnoi informatsii $u$ movnii kartyni svitu [Concept of culture as a unit of mental information in the world language picture]. Mandrivets. 2014. № 1. S. 53-57.

13. Skab M. V. Kontseptualizatsiia sakralnoi sfery v ukrainskii movi [Conceptualization of the sacred sphere in the Ukrainian language] : avtoref. dys. ... d-ra filoloh. nauk : 10.02.01. Kyiv, 2009. $36 \mathrm{~s}$.

14. Slovar ukrainskoi movy : u 4-kh t. [Ukrainian language dictionary] / za red. B. D. Hrinchenka. Kyiv, 1907-1909. URL : https://r2u.org.ua/data/Slovar ukrainskoimovy (1907-1909). pdf (data zvernennia: 15.10.2018).

15. Slovnyk ukrainskoi movy : v 11-ty t. [Ukrainian language dictionary] / AN URSR. Instytut movoznavstva ; za red. I. K. Bilodida. Kyiv, T. 3. 1972. 744 s.

16. Filosofskyi entsyklopedychnyi slovnyk [Philosophical encyclopaedic dictionary] / holov. red. V. I. Shynkaruk. Kyiv, 2002. 742 s. URL : http://shron1. chtyvo.org.ua/Shynkaruk_Volodymyr/Filosofskyi_entsyklopedychnyi_slovnyk.pdf (data zvernennia: 14.10.2018).

Стаття надійшла до редакиії 22.06.2018 p. Прийнята до друку 15.11. 2018 . 